\title{
Systematic Review of the Non-Specific Effects of Bacillus Calmette-Guérin Vaccine on Child Mortality
}

\author{
Cintia Tavares Cruz ${ }^{1}$, Bruna Almeida ${ }^{2}$, Eduardo Troster ${ }^{3}$ and Cardim Oliveira ${ }^{3}$ \\ ${ }^{1}$ Institute of Childhood Cancer Treatment, Hospital das Clínicas, Medical School, University of São Paulo, Brazil \\ ${ }^{2}$ Institute of the Child of the Clinical Hospital, University of São Paulo, Brazil \\ ${ }^{3}$ Course of Medicine, Albert Einstein College of Medicine, USA
}

Corresponding author: Cruz Tavares Cintia, Institute of Childhood Cancer Treatment, Hospital das Clínicas, Medical School, University of São Paulo, Brazil, Tel: +55 11 986374612; E-mail: cintiatcruz@gmail.com

Received date: May 16, 2017; Accepted date: June 05, 2017; Published date: June 10, 2017

Copyright: @ 2017 Cruz CT, et al. This is an open-access article distributed under the terms of the Creative Commons Attribution License, which permits unrestricted use, distribution, and reproduction in any medium, provided the original author and source are credited.

Citation: Cruz CT, Almeida B, Troster E, et al. Systematic Review of the Non-Specific Effects of Bacillus Calmette-Guérin Vaccine on Child Mortality. J Infec Dis Treat. 2017, 3:1.

\section{Abstract}

Background: Until a different vaccine is given, BCG provides non-specific protection against diseases other than tuberculosis, mainly respiratory infections and sepsis.

Methods: A systematic review was made using the databases Medline, Lilacs, Cochrane Library, Scopus and the WHO review of BCG, using the terms BCG, nonspecific effects, heterologous immunity, and child mortality. The objective was to quantify the effect of BCG on all-cause mortality until a different vaccine was given in children up to 5 years of age in low-income countries. Randomized trials and observational studies performed in low-income populations where all-cause mortality was reported were selected.

Results: Fifty-nine articles were found. Nine studies had a low to moderate risk of bias; they consisted of two randomized trials, six cohort studies and one case-control study; they were performed in Guinea-Bissau, India, Benin, Malawi and Senegal. The effect estimates were homogeneous, with $12=0.0 \%(p=0.71)$. Meta-analysis of all nine studies using a random effects model yielded an effect estimate of 0.56 ( $95 \% \mathrm{Cl} 0.46-0.69)$. The combined estimate for the two randomized trials of BCG-Denmark that had a low risk of bias was 0.52 ( $95 \% \mathrm{Cl} 0.33-0.82$ ).
Conclusions: The two randomized trials and the seven observational studies suggests that, until a different vaccine is given, administration of the strains of BCG used in these studies approximately halved all-cause mortality in children under five years of age in these low-income countries.

Keywords: Vaccine; Tuberculosis; Mortality rate

Abbreviations: BCG: Bacillus Calmette-Guérin vaccine; DTP: Diphtheria-Tetanus-Pertussis Vaccine; WHO: World Health Organization.

\section{Introduction}

Worldwide between 1990 and 2015, the under 5 years of age (under 5) mortality rate decreased from 90 to 43 deaths per 1000 live births, and the annual number of under 5 deaths halved from 12.7 million to 5.9 million [1]. However, 5.9 million deaths per year is still far too many. If the whole world had the under 5 mortality rate of 3 per 1000 live births seen in Japan, Norway, Singapore and Sweden, there would have been only 0.4 million under 5 deaths worldwide in 2015 rather than 5.9 million. So, there were the possibility of avoiding 5.5 million deaths of children under 5 years in 2015, a very impacting number for the families well being and for the nations. According to the World Health Organization (WHO), most of the 5.5 million excess deaths were caused by infections [2]. 


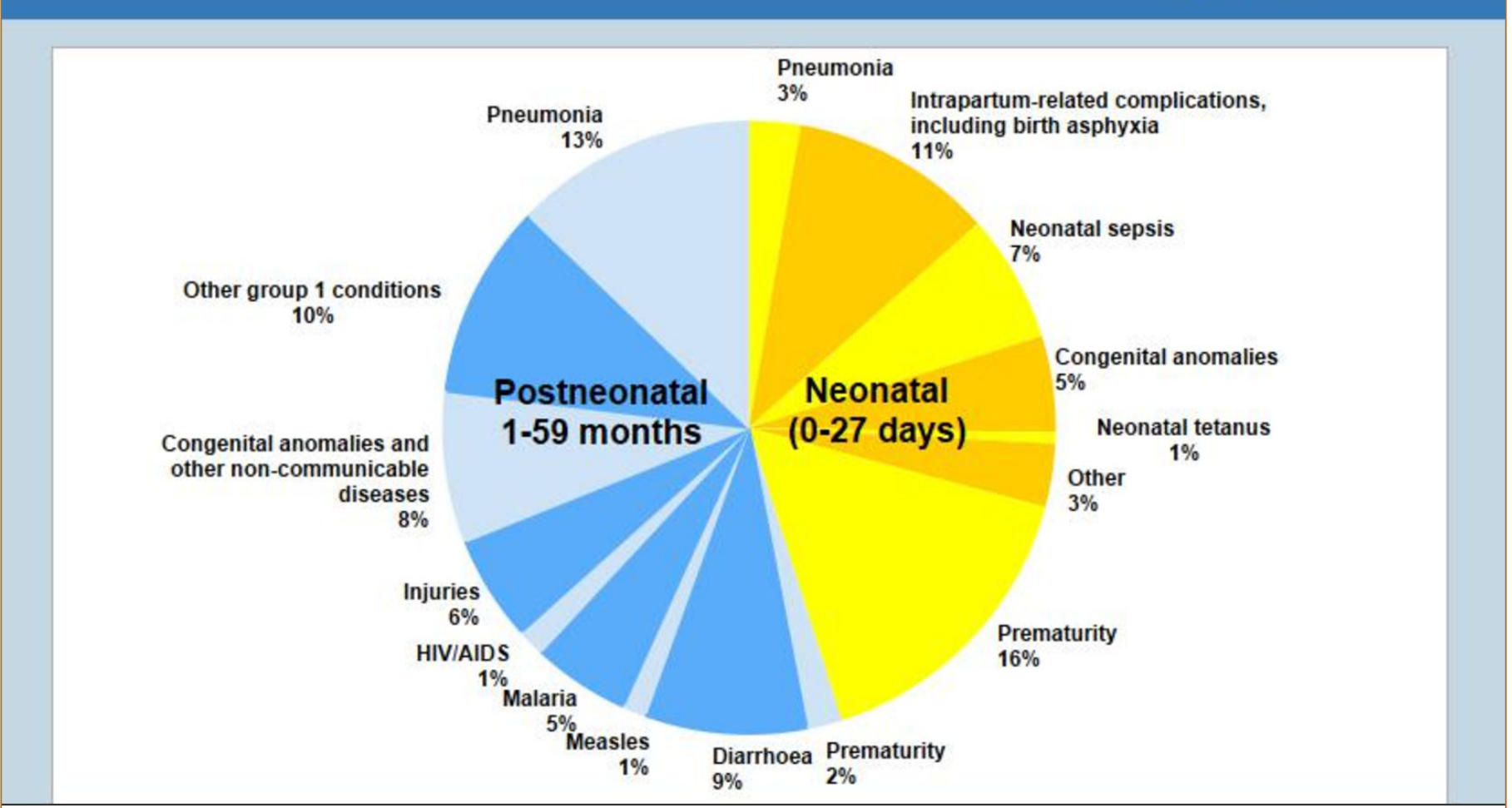

Figure 1 Causes of child mortality in 2015, from World Health Organization database.

In studies in the United States and the United Kingdom in the years 1940 to 1950, Bacillus Calmette-Guérin (BCG) vaccine was associated with a $25 \%$ reduction in all-cause child mortality from diseases other than tuberculosis [3]. Subsequently, observational studies in countries with high infant mortality rates supported these findings [4]. In 2014, a cohort study in 18 countries reported a reduction of $17 \%$ to $37 \%$ in the risk of acquiring lower airways respiratory disease in children under 5 years old vaccinated with BCG [5]. In 2014, a review of the non-specific effects of BCG performed for the World Health Organization (WHO) concluded that "the estimated effects are in the region of a halving of mortality risk", and pointed out that deaths from tuberculosis are infrequent in the first five years of life, "so any effect of BCG vaccine on all-cause mortality is not likely to be attributable to any great extent to fewer deaths from tuberculosis" [6].

WHO recommends BCG vaccination as soon as possible after birth in countries with a high incidence of tuberculosis [7]. For preterm infants with gestational age below 36 weeks, vaccination is recommended just after the child reaches one month of age. However, many children in high-mortality regions are not vaccinated with BCG at birth [8] (Figure 1).

Because of the potential importance of the finding that, until a different vaccine is given, BCG may be associated with substantial reductions in mortality in children less than 5 years of age, we performed a systematic review of studies of the effect of giving BCG on all-cause mortality in children in lowincome countries.

\section{Methods}

A systematic review was made using the databases Medline, Lilacs, Cochrane Library, Scopus and the WHO review of BCG, using the terms BCG, non-specific effects, heterologous immunity, and child mortality. Articles published up to January 2015 were included. The search strategy was individualized for each database and the bibliography of articles searched for further studies. The inclusion criteria were randomized trails, cohort studies and case-control studies performed in lowincome populations with high under 5 mortality rates where all-cause mortality was reported and the article was written in English, Portuguese or Spanish. The titles and abstracts were reviewed by two authors; articles that did not fulfill the inclusion criteria for population and intervention were excluded. The selected articles had their full text read and critically appraised. Where available, the effect of BCG on mortality from both tuberculosis and other causes of death was noted. The exclusion criteria were BCG vaccination after five years of age, articles about the non-specific effects of BCG that did not report under 5 mortality, and studies that did not report subsequent mortality separately for BCG alone when a substantial proportion of children received whole-cell diphtheria-tetanus pertussis vaccine (DTP) or measles vaccine with or after BCG. Because of the evidence that BCG made by 
different manufacturers may have very different clinical properties [9], the strain of BCG used was noted where possible. Statistical analysis was performed using Stata version 14.1 (Statacorp, College Station, Texas).

\section{Results}

Fifty-nine articles were found, 15 were eligible for detailed analysis, and nine were included in the final analysis (Figures 2 and 3; Table 1) [10-18]. The nine studies with a low to moderate risk of bias consisted of two randomized trials, six cohort studies and one case-control study. The studies were performed in Guinea-Bissau (four studies), India (two studies), Benin, Malawi and Senegal.

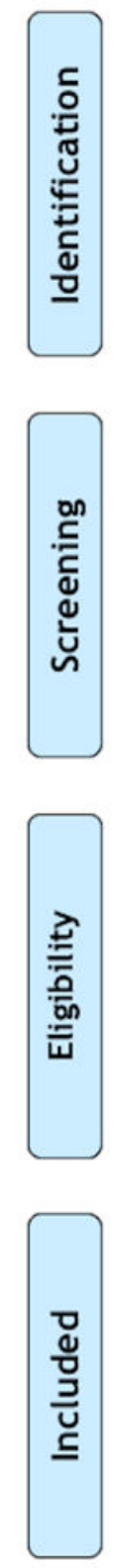

\section{Records identified through da- tabase searching} $(n=59)$
Additional records identified through other sources $(n=0)$

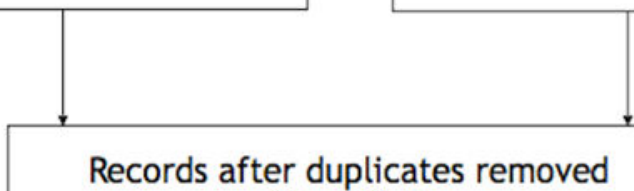

$(n=59$ )

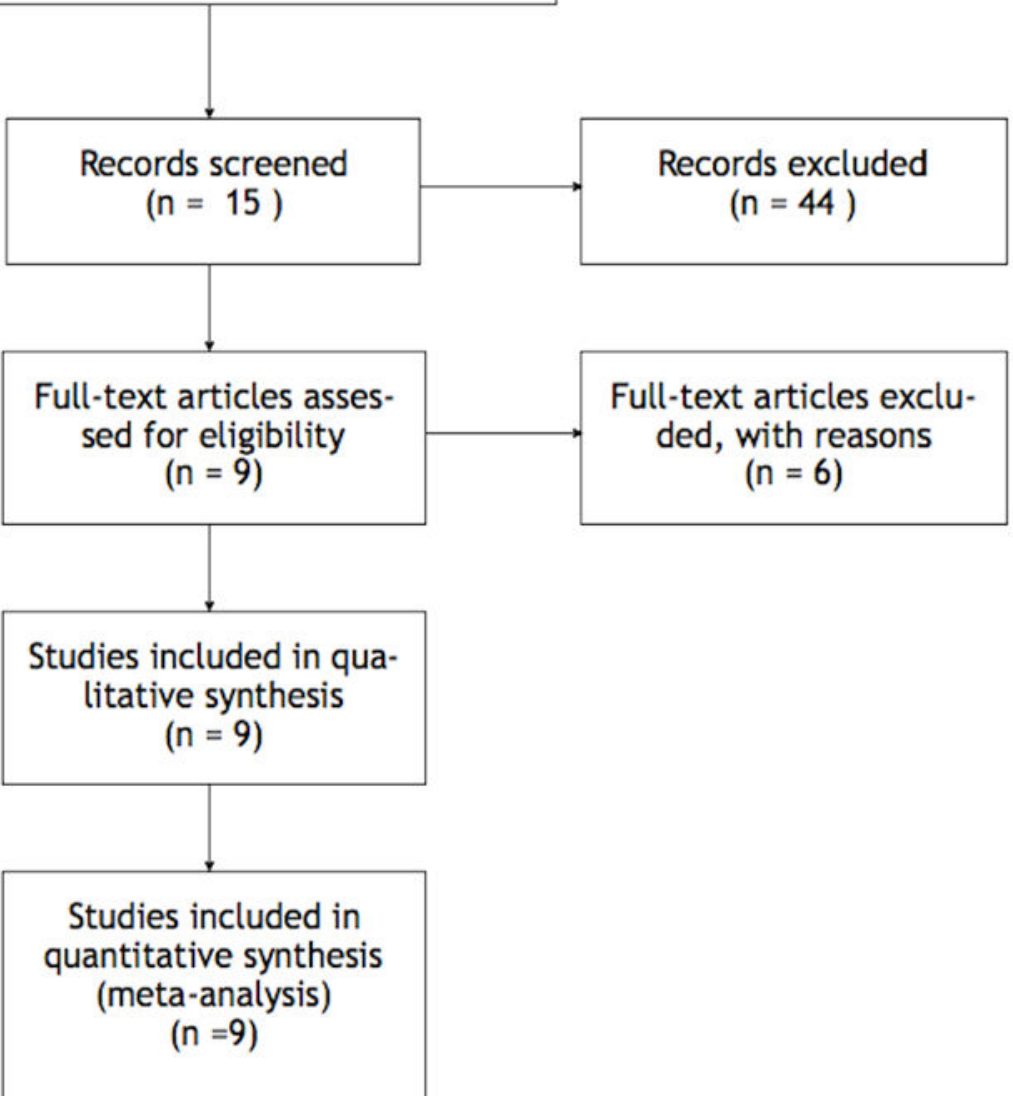

Figure 2 Flow diagram. 


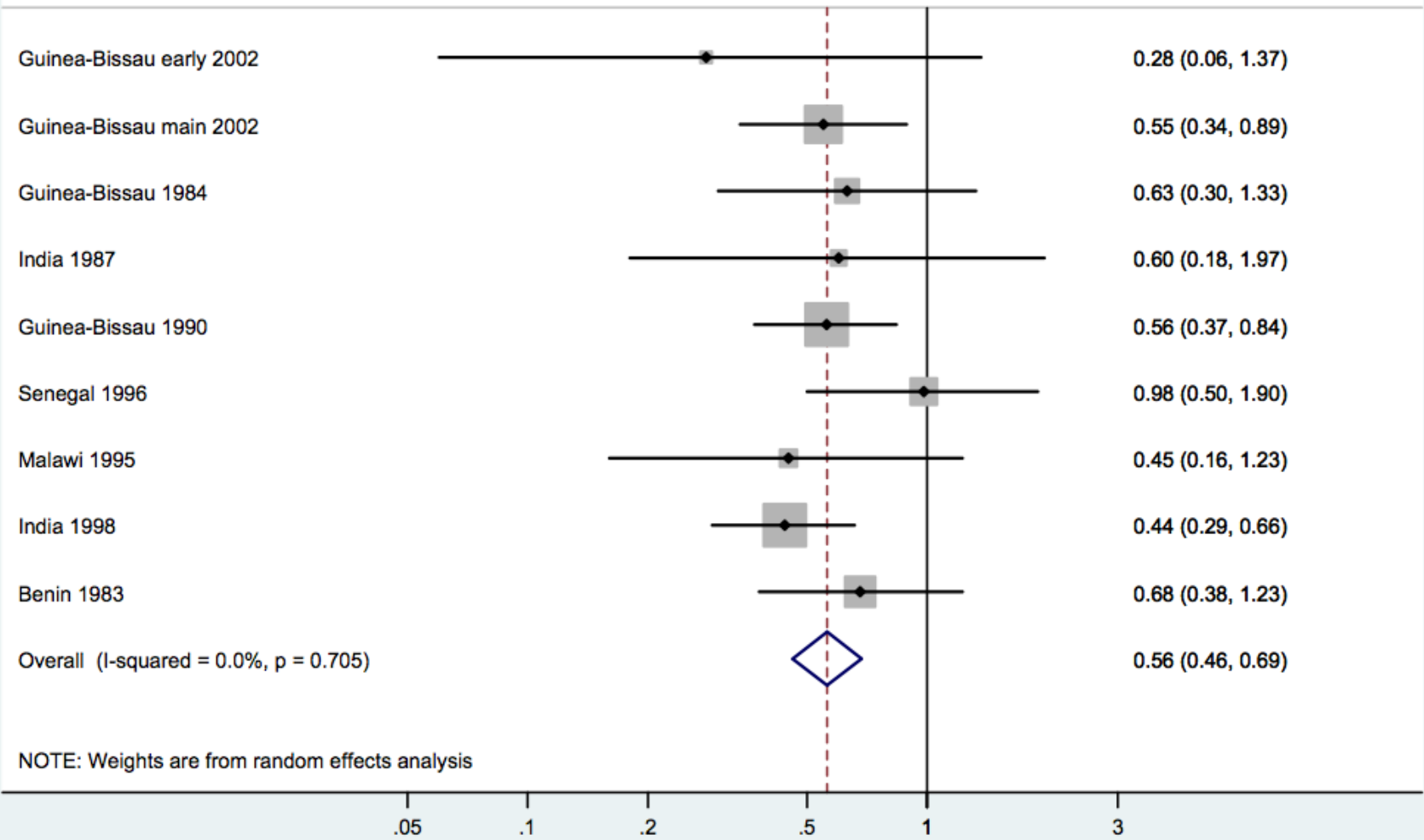

Figure 3 Forest plot of studies of the effect of BCG on all-cause mortality in children under 5 years of age in high-mortality countries (ES=effect size).

Table 1 Studies of the effect of BCG on all-cause mortality in children under 5 years of age in high-4-mortality countries.

\begin{tabular}{|c|c|c|c|c|c|c|c|c|}
\hline \multicolumn{2}{|c|}{ Studies included in this analysis } & $\begin{array}{l}\text { Number } \\
\text { of } \\
\text { children }\end{array}$ & Age & $\begin{array}{l}\text { Assessment of } \\
\text { unvaccinated } \\
\text { status }\end{array}$ & Confounding & $\begin{array}{l}\text { Subsequent } \\
\text { DTP }\end{array}$ & Adjustment & Effect \\
\hline $\begin{array}{l}\text { Guinea-Bissau } \\
2002-3003\end{array}$ & $\begin{array}{l}\text { Blenng-Saann. } \\
\text { P1DJ 2012; } \\
31: 306-8\end{array}$ & 105 & $0-4 w$ & $\begin{array}{l}\text { Randaomized } \\
\text { trial }\end{array}$ & Low & None & Age & $\begin{array}{l}0.28 \\
(0.06-1 \\
.37)\end{array}$ \\
\hline $\begin{array}{l}\text { Guinea-Bissau } \\
2002-2008\end{array}$ & $\begin{array}{lr}\text { Aaby, } & \text { JID } \\
2011 ; & 204: \\
245-52 & \end{array}$ & 2320 & $0-4 w$ & $\begin{array}{l}\text { Randaomized } \\
\text { trial }\end{array}$ & Low & None & Age & $\begin{array}{l}0.55 \\
(0.34-0 \\
.89)\end{array}$ \\
\hline $\begin{array}{l}\text { Guinea-Bissau } \\
1984-1985\end{array}$ & $\begin{array}{ll}\text { Aaby, } & \text { IJE } \\
2004 ; & 33: \\
374-80 & \end{array}$ & 1657 & $2-8 m$ & $\begin{array}{l}\text { BCG given by } \\
\text { researchers }\end{array}$ & Moderate & Many & $\begin{array}{l}\text { Age, Sex, DTP, } \\
\text { other }\end{array}$ & $\begin{array}{l}0.63 \\
(0.30-1 \\
.33)\end{array}$ \\
\hline $\begin{array}{l}\text { India } \\
1987-1989\end{array}$ & $\begin{array}{lr}\text { Hirve, } & \text { Vaccine } \\
2012 ; & 30: \\
7300-8 & \end{array}$ & 3072 & $0-12 m$ & $\begin{array}{l}\text { Vaccination card, } \\
34 \% \text { not seen }\end{array}$ & Moderate & None & None & $\begin{array}{l}0.60 \\
(0.18-1 \\
.97)\end{array}$ \\
\hline $\begin{array}{l}\text { Guinea-Bissau } \\
\text { 1990-1996 }\end{array}$ & $\begin{array}{l}\text { Aaby, BMJ } \\
2002 \text { online; } \\
2011 / 10 / 29\end{array}$ & 5274 & $\begin{array}{l}1-6 \mathrm{~m} \text { follow } \\
\text { up }\end{array}$ & $\begin{array}{l}\text { Vaccination card, } \\
7 \% \text { not seen }\end{array}$ & Moderate & Many & Age, other & $\begin{array}{l}0.56 \\
(0.37-0 \\
.84)\end{array}$ \\
\hline
\end{tabular}




\begin{tabular}{|c|c|c|c|c|c|c|c|c|}
\hline $\begin{array}{l}\text { Senegal } \\
1996-1999\end{array}$ & $\begin{array}{lr}\text { Aaby, } & \text { TRSTMH } \\
2015 ; & 109: \\
77-84 & \end{array}$ & 4120 & $\begin{array}{l}44 \% \text { by } 12 \\
m \text { to } 24 \mathrm{~m}\end{array}$ & $\begin{array}{l}\text { no card assumed } \\
\text { unvaccinated }\end{array}$ & Moderate & Many censored & Age, Sex, other & $\begin{array}{l}0.98 \\
(0.50-1 \\
.23)\end{array}$ \\
\hline $\begin{array}{l}\text { Malawi } \\
1995-1997\end{array}$ & $\begin{array}{lr}\text { Aaby, } & \text { PIDJ } \\
2006 ; & 25: \\
721-7 & \end{array}$ & 751 & $0-6 \mathrm{~m}$ & $\begin{array}{l}\text { clinic register, } \\
29 \% \text { dead card } \\
\text { unseen }\end{array}$ & Moderate & Many censored & Age, other & $\begin{array}{l}0.45 \\
(0.16-1 \\
.23)\end{array}$ \\
\hline $\begin{array}{l}\text { India } \\
1998-2002\end{array}$ & $\begin{array}{lr}\text { Moulton, } & \text { TMIH } \\
2005 ; & 10: \\
947-55 & \end{array}$ & 10274 & $0-6 \mathrm{~m}$ & Home interview & Moderate & Many censored & Age & $\begin{array}{l}0.44 \\
(0.29-0 \\
.66)\end{array}$ \\
\hline $\begin{array}{l}\text { Benin } \\
1983-1987\end{array}$ & $\begin{array}{ll}\text { Velema, } & \text { IJE } \\
1991 ; & 20: \\
474-9 & \end{array}$ & 294 & $\begin{array}{l}\text { Observed } \\
4-36 \mathrm{~m}\end{array}$ & $\begin{array}{l}\text { Clinic register, } \\
\text { Case-control } \\
\text { study }\end{array}$ & Moderate & Many & Age, Sex, other & $\begin{array}{l}0.68 \\
(0.38-1 \\
.23)\end{array}$ \\
\hline \multicolumn{9}{|c|}{ Studies included in the WHO analysis but excluded from this analysis } \\
\hline PNG 1989-94 & $\begin{array}{l}\text { Lehmann, IJE } \\
\text { 2005;34: } \\
\text { 138-48 }\end{array}$ & 3937 & $0-6 \mathrm{~m}$ & $\begin{array}{l}\text { no card assumed } \\
\text { unvaccinated }\end{array}$ & $\begin{array}{l}\text { High: } \\
\text { Unvaccinated } \\
233 / 1000 \text { died }\end{array}$ & Many & $\begin{array}{l}\text { Age, } \\
\text { other }\end{array}$ & $\begin{array}{l}0.17 \\
(0.09-0 \\
.34)\end{array}$ \\
\hline $\begin{array}{l}\text { Guinea-Bissau } \\
1989-1999\end{array}$ & $\begin{array}{lr}\text { Roth, } & \text { PIDJ } \\
2004 ; & 23: \\
544-50 & \end{array}$ & 695 & $0-6 \mathrm{~m}$ & Vaccination card & & Many & Age, Sex, other & $\begin{array}{l}0.05 \\
(0.01-0 \\
.46)\end{array}$ \\
\hline \multicolumn{9}{|c|}{ Studies excluded from both the WHO analysis and this analysis } \\
\hline $\begin{array}{l}\text { Burkina Faso } \\
1985-1993\end{array}$ & $\begin{array}{l}\text { Vaugelade, } \\
\text { BMJ 2004; } \\
\text { 329: 1309-11 }\end{array}$ & 9085 & $\begin{array}{lr}\text { Mean } & 4.8 \\
\mathrm{~m}, \quad 6 \quad \mathrm{~m} \\
\text { follow up }\end{array}$ & $\begin{array}{l}\text { No card assumed } \\
\text { unvaccinated }\end{array}$ & High & Some with DTP & Age, other & $\begin{array}{l}0.5 \\
(0.34-0 \\
.75)\end{array}$ \\
\hline $\begin{array}{l}\text { Bangladesh } \\
1986-2001\end{array}$ & $\begin{array}{l}\text { Breiman, } \\
\text { Lancet 2004; } \\
364: 2204-11\end{array}$ & 37894 & $0-60 \mathrm{~m}$ & $\begin{array}{l}\text { No card assumed } \\
\text { unvaccinated }\end{array}$ & High & Many with DTP & Age & $\begin{array}{l}0.2 \\
(0.07-0 \\
.54)\end{array}$ \\
\hline $\begin{array}{l}\text { Ghana } \\
\text { 1998-2004 }\end{array}$ & $\begin{array}{l}\text { Bawah, } \\
\text { ScjPubHlth } \\
\begin{array}{ll}2010 ; & 38: \\
95-103\end{array}\end{array}$ & 17967 & $\begin{array}{l}57 \% \text { by } 12 \\
\mathrm{~m} \text { to } 60 \mathrm{~m}\end{array}$ & $\begin{array}{l}\text { No card assumed } \\
\text { unvaccinated }\end{array}$ & High & Many & Age, other & $\begin{array}{l}0.18 \\
(0.17-0 \\
.20)\end{array}$ \\
\hline $\begin{array}{l}\text { India } \\
2006-2011\end{array}$ & $\begin{array}{l}\text { Krishnan, } \\
\text { TMIH 2013; 18: } \\
\text { 1329-37 }\end{array}$ & 11390 & $0-5 w$ & $\begin{array}{l}\text { Clinic Record, } \\
\text { else assumed } \\
\text { unvaccinated }\end{array}$ & $\begin{array}{ll}\text { High: } & \text { Age } \\
\text { Cofounding } & \end{array}$ & Few & None & $\begin{array}{l}0.12 \\
(0.09-0 \\
.16)\end{array}$ \\
\hline
\end{tabular}

Two studies that were included in the WHO analysis of the non-specific effects of BCG were excluded from this analysis because they had a very high risk of bias (Table 1). The study in Papua New Guinea had a very high mortality rate of 233 per 1000 person years among unvaccinated children aged 1-5 months compared to only 31 per 1000 person years in vaccinated children, in a region with a 0-12 month mortality of 68 per 1000 live births at the time. Frailty bias occurred because government policy was that children should not be immunized if they were unwell, so unvaccinated children were a high-risk group. In the cohort study of low-birth-weight infants in Guinea-Bissau, babies were vaccinated as they reached $2.5 \mathrm{~kg}$ weight, so unvaccinated time was greater in low-weight high-risk infants and vaccinated time was greater in heavier lower-risk children, introducing frailty bias. Four cohort studies were excluded from both this analysis and the WHO analysis because of high risk of bias (Table 1). Most studies did not state the strain of BCG used.

In the nine studies included in this analysis, meta-analysis showed that the effect estimates were homogeneous, with $12=0.0 \%$, with $\mathrm{p}=0.71$ (Figure 2). A fixed effects model yielded an effect estimate of 0.56 (95\% confidence interval 0.46-0.67) and a random effects model yielded 0.56 (95\% Cl 0.46-0.69). The combined estimate for the two randomized trials of BCG-
Denmark in Guinea-Bissau that had a low risk of bias was 0.52 (95\% Cl 0.33-0.82).

The WHO analysis included three pseudo-randomized trials performed in North America in the 1930s and 1940s, as well as the two cohort studies from Papua New Guinea and GuineaBissau that were excluded from this analysis because of bias $[19,20]$. Meta-analysis showed substantial heterogeneity in the 14 WHO studies with $12=62 \%(p=0.001)$, but the random effects estimate of $0.53(95 \% \mathrm{Cl} 0.40-0.72)$ was very similar to the random effects estimate of $0.52(95 \% \mathrm{Cl} 0.33-0.82)$ from the nine studies in our analysis [21-24].

\section{Discussion}

Cohort studies overestimate the beneficial effects of BCG if they are subject to frailty bias (when ill children are not vaccinated), ascertainment bias (children with no vaccination record who die are assumed to be unvaccinated when some are vaccinated), and survival bias (if vaccination status is determined retrospectively and vaccination cards are destroyed when a child dies) [25-27]. On the other hand, cohort studies will underestimate the beneficial effects of BCG if they are subject to age bias (when younger unvaccinated children at high risk of dying are compared to older vaccinated 
children), if no allowance is made for administration during follow-up of beneficial vaccines such as BCG or measles vaccine or oral polio vaccine, or if no allowance is made for DTP given with or after BCG (as DTP reduces the benefit from BCG) $[28,29]$.

Our selection of cohort studies was designed to minimize the risk of major bias. We excluded Papua New Guinea 1989-1994 and Guinea-Bissau 1989-1999 because there was evidence of substantial frailty bias in these studies $[19,20]$. Three other cohort studies were excluded because of coadministration of DTP, and the assumption that children were unvaccinated if there was no record of their having a vaccination card (especially if no children were censored for lack of information) [21-23]. Another study was excluded because the analysis was not adjusted for age, and the BCGunvaccinated children were younger than BCG-vaccinated children [30]. Evidence that we eliminated major sources of bias is provided by the finding that the combined estimate for the seven observational studies of 0.57 (95\% $\mathrm{Cl} 0.46-0.71)$ was similar to the combined estimate for the two randomized trials of 0.52 (95\% $\mathrm{Cl} 0.33-0.82)$; the randomized trials had a low risk of bias. This large reduction in all-cause mortality, largely because of fewer deaths from pneumonia and sepsis [10-11], was not due to a specific effect of BCG on mycobacterial infection because tuberculosis is an uncommon cause of death in the first five years of life [6].

BCG is likely to be more effective when child mortality is very high and most deaths are caused by infection; as mortality falls, a higher proportion of deaths are due to noninfectious causes that are unlikely to be prevented by BCG.

The most likely mechanism for the beneficial effect of BCG is an alteration in innate immune function, which would explain why an effect is seen early in the first 1-3 days after vaccination. 30 In adults, immunization with the BCG vaccine leads to elevated production of the pro-inflammatory cytokines tumor-necrosis factor and interleukin $1 \mathrm{~b}$ in response to non- BCG-related stimuli that is maintained for up to 3 months after vaccination. Furthermore, monocytes recovered 1 year after such vaccination still display increased expression of the co-receptor CD14, pattern-recognition receptors (for example, Toll-like receptor 4) and the receptor for mannose. The underlying molecular mechanisms that lead this sustained alteration in function of the innate immune system following immunization with the BCG vaccine appear to relate to changes in the epigenetic regulation of gene expression following innate stimulation. The effect on innate immunity is at least in part due to an epigenetic mechanism mediated by methylation of histone. 31 In other words, exposure to BCG changes both the phenotype as the circulation status of mononuclear cells, increasing CD14+ number of monocytes and their receptors expression. In addition, it is known that modification of histones (acetylation or methylation) is crucial in regulating the inflammatory response in the body and it was observed that vaccination with BCG increases the trimethylation of histone $\mathrm{H} 3$ in lysine $\mathrm{K} 4$ (H3K4). In a combination of studies In vivo and In vitro, it has been demonstrated that an epigenetic change NOD2 mediated at the level of histone methylation is the mechanism by which BCG acts in the immune system. So, it was concluded that monocytes can be reprogrammed and "trained" to a new phenotype acquired after vaccination with BCG and it can cause two types of immune responses: 1 . classical and induces a specific immune response involving antigen specificity by $T$ cells and immunological memory leading to protection against tuberculosis, 2 . induces adaptive response based on reprogramming the mononuclear phagocyte system, which results in protection against other infections other than tuberculosis. It is possible that changes in innate immunity following such immunization differ according to age and sex of the recipients; age-dependent differences between infants and adults have been noted in their innate immunity in general and in their response to the BCG vaccine in particular [30-32].

There is evidence that BCG vaccine produced by different manufacturers has very different clinical effects. Unfortunately, most investigators did not record the strain of BCG that was used in the studies reported here. We know that BCG-Denmark was used in the two randomized trials in lowbirth-weight babies in Guinea-Bissau $[9,10]$, but it cannot be assumed that other strains of BCG will have the same effect. BCG-Denmark and BCG-Japan both contain at least two different genomes, which may explain the considerable variation in clinical effects between batches from individual manufacturers. We need to determine what genomes are in all the BCG products made by the major manufacturers, determine the most effective genome, and standardize production using that genome.

The evidence that BCG has beneficial non-specific effects has important implications for policy [32]. In addition to developing a vaccine based on the most effective genome, we need to ensure that as many children as possible are given BCG at birth in high-mortality countries. Although it is policy for BCG to give at the time of birth, the vaccine is usually supplied in 20-dose vials and many clinics do not open a vial until they have 8-12 infants to immunize, so most neonates do not currently get BCG at birth. In addition, if a new vaccine is developed that provides better protection than BCG against tuberculosis in older children and adults, there will be a strong case for continuing to give BCG to neonates to provide the beneficial non-specific effects.

The evidence that BCG approximately halves all-cause mortality suggests that substantial further reductions in child mortality could be achieved by giving BCG at birth to all babies in high-mortality countries, and by identifying the BCG genome that provides the most effective protection against tuberculosis and infections other than tuberculosis. We urgently need randomized trials of other BCG strains in addition to the two trials of BCG-Denmark that have been performed in Guinea-Bissau.

\section{Funding Source}

None. 


\section{Financial Disclosure}

The authors have no financial relationships relevant to this article to disclose.

\section{Conflict of Interest}

The authors have no conflicts of interest to disclose.

\section{Clinical Trial Registration}

Not registered.

\section{Contributors' Statements}

Cintia Cruz: Dra Cruz conceptualized and designed the study, designed the data collection instruments, reviewed the selected articles, carried out the initial analyses, reviewed and revised the manuscript and approved the final manuscript as submitted.

Bruna Almeida: Dra Almeida conceptualized and designed the study, designed the data collection instruments, reviewed the selected articles, carried out the initial analyses, reviewed and revised the manuscript and approved the final manuscript as submitted.

Eduardo Troster: Dr Troster conceptualized and designed the study, designed the data collection instruments and coordinated and supervised data collection, critically reviewed the manuscript, and approved the final manuscript as submitted.

Cardim Oliveira: Dr Cardim conceptualized and designed the study, designed the data collection instruments, worked on the statistical analyses, critically reviewed the manuscript, and approved the final manuscript as submitted.

All authors approved the final manuscript as submitted and agree to be accountable for all aspects of the work.

\section{References}

1. UNICEF (2016) The State of the World's Children 2016: A Fair Chance Every Child. Accessed on: 18 July 2016.

2. World Health Organization. Global Health Observatory (GHO) data-Causes of child mortality. Accessed on: 31 May 2017.

3. Shann $F(2010)$ The non-specific effects of vaccines. Arch Dis Child 95: 662-667.

4. Roth A, Garly ML, Jensen H, Nielsen J, Aaby P (2006) Bacillus Calmette-Guérin vaccination and infant mortality. Expert Rev Vaccines 5: 277-293.

5. Hollm-Delgado M-G, Stuart EA, Black RE (2014) Acute Lower Respiratory Infection Among Bacille Calmette-Guerin (BCG)Vaccinated Children. Pediatrics 133: e73-81.

6. Higgins J, Soares-Weiser K, Reingold A (2014) Systematic review of the non-specific effects of BCG, DTP and measles containing vaccines. Accessed on: 18 July 2016.

7. World Health Organization (2004) BCG vaccine. WHO position paper. Wkly Epidemiol Rec 79: 27-38.
8. Clark A, Sanderson C (2009) Timing of children's vaccinations in 45 low-income and middle-income countries: an analysis of survey data. Lancet 373: 1543-1549.

9. Shann F (2015) Different strains of Bacillus Calmette-Guérin vaccine have very different effects on tuberculosis and on unrelated infections. Clin Infect Dis 61: 960-962.

10. Biering-Sorensen S, Aaby P, Napirna B (2012) Small randomized trial among low-birth-weight children of Bacillus CalmetteGuerin vaccination at first health center contact. Pediatr Infect Dis J 31: 306-308.

11. Aaby P, Roth A, Ravn H (2011) Randomized trial of BCG vaccination at birth to low-birth-weight children: beneficial nonspecific effects in the neonatal period. J Infect Dis 204: 245-252.

12. Aaby P, Jensen H, Gomes J, Fernandes M, Lisse IM (2004) The introduction of diphtheria-tetanus-pertussis vaccine and child mortality in rural Guinea-Bissau: an observational study. Int J Epidemiol 33:374-380.

13. Hirve S, Bavdekar A, Juvekar S, Benn CS, Nielsen J, et al. (2012) Non-specific and sex-differential effects of vaccinations on child survival in rural western India. Vaccine 30: 7300-7308.

14. Aaby $P$, Jensen $H$ (2002) Routine vaccinations and child survival: effect of gender | BMJ. Decemberroutine-vaccinations-andchild-survival-effect-gender. Accessed on: 23 March 2013.

15. Aaby P, Nielsen J, Benn CS, Trape JF (2015) Sex-differential and non-specific effects of routine vaccinations in a rural area with low vaccination coverage: an observational study from Senegal. Trans R Soc Trop Med Hyg 109: 77-84.

16. Aaby $P$, Vessari $H$, Nielsen J (2006) Sex differential effects of routine immunizations and childhood survival in rural Malawi. Pediatr Infect Dis J 25: 721-727.

17. Moulton LH, Rahmathullah L, Halsey NA, Thulasiraj RD, Katz J (2005) Evaluation of non-specific effects of infant immunizations on early infant mortality in a southern Indian population. Trop Med Int Health 10: 947-955.

18. Velema JP, Alihonou EM, Gandaho T, Hounye FH (1991) Childhood mortality among users and non-users of primary health care in a rural west African community. Int J Epidemiol 20: 474-479.

19. Lehmann D, Vail J, Firth MJ, de Klerk NH, Alpers MP (2005) Benefits of routine immunizations on childhood survival in Tari, Southern Highlands Province, Papua New Guinea. Int J Epidemiol 34: 138-148.

20. Roth A, Jensen H, Garly ML (2004) Low birth weight infants and Calmette-Guérin bacillus vaccination at birth: community study from Guinea-Bissau. Pediatr Infect Dis J 23: 544-550.

21. Vaugelade J, Pinchinat S, Guiella G, Elguero E, Simondon F (2004) Non-specific effects of vaccination on child survival: prospective cohort study in Burkina Faso. BMJ 329: 1309.

22. Breiman RF, Streatfield PK, Phelan M, Shifa N, Rashid M, et al. (2004) Effect of infant immunisation on childhood mortality in rural Bangladesh: analysis of health and demographic surveillance data. Lancet 364: 2204-2211.

23. Bawah AA, Phillips JF, Adjuik M, Vaughan-Smith M, Macleod B, et al. (2010) The impact of immunization on the association between poverty and child survival: evidence from KassenaNankana District of northern Ghana. Scand J Public Health 38: 95-103. 
24. Krishnan A, Srivastava R, Dwivedi P, Ng N, Byass P, et al. (2013) Non-specific sex-differential effect of DTP vaccination may partially explain the excess girl child mortality in Ballabgarh, India. Trop Med Int Health 18: 1329-1337

25. Ferguson RG, Simes AB (1949) BCG vaccination of Indian infants in Saskatchewan. Tubercle 30: 5-11.

26. Aronson JD (1948) Protective vaccination against tuberculosis with special reference to BCG vaccination. Am Rev Tuberc 58: 255-281.

27. Rosenthal SR, Loewinsohn E, Graham ML, Liveright $D$, Thorne MG, et al. (1961) BCG vaccination in tuberculous households. Am Rev Respir Dis 84: 690-704.

28. Farrington $\mathrm{CP}$, Firth MJ, Moulton $\mathrm{LH}$, Ravn H, Andersen PK, et al. (2009) Epidemiological studies of the non-specific effects of vaccines: Il--methodological issues in the design and analysis of cohort studies. Trop Med Int Health 14: 977-985.
29. Aaby P, Benn C, Nielsen J, Lisse IM, Rodrigues A, et al. (2012) Testing the hypothesis that diphtheria-tetanus-pertussis vaccine has negative non-specific and sex-differential effects on child survival in high-mortality countries. BMJ Open 2.

30. Aaby P, Kollmann TR, Benn CS (2014) Nonspecific effects of neonatal and infant vaccination: public-health, immunological and conceptual challenges. Nat Immunol 15: 895-899.

31. Kleinnijenhuis J, Quintin J, Preijers F (2012) Bacille CalmetteGuerin induces NOD2-dependent nonspecific protection from reinfection via epigenetic reprogramming of monocytes. Proc Natl Acad Sci USA 109: 17537-17542.

32. Shann $F$ (2015) The heterologous (non-specific) effects of vaccines: implications for policy in high-mortality countries. Trans R Soc Trop Med Hyg 109: 5-8. 